Taxonomy and systematics

\title{
Parasitic nematodes of three species of wild carnivore mammals from Atlantic forest in the state of Minas Gerais, Brazil
}

\section{Nemátodos parásitos de tres especies de mamíferos carnívoros silvestres del bosque atlántico en el estado de Minas Gerais, Brasil}

\author{
Fabiano Matos Vieira ${ }^{a}$, Luís Claudio Muniz-Pereira ${ }^{\mathrm{a}}$, Sueli de Souza-Lima ${ }^{\mathrm{b}}$, \\ Bárbara Marun Rocha ${ }^{b, *}$, José Luis Luque ${ }^{c}$ \\ ${ }^{a}$ Laboratório de Helmintos Parasitos de Vertebrados, Instituto Oswaldo Cruz, FIOCRUZ, Av. Brasil 4365, Rio de Janeiro CEP 21040-900, Brazil \\ ${ }^{\mathrm{b}}$ Laboratório de Ecologia e Taxonomia de Helmintos - Odile Bain, Departamento de Zoologia, Universidade Federal de Juiz de Fora (UFJF), Juiz de Fora, Minas \\ Gerais, Brazil \\ ${ }^{\mathrm{c}}$ Departamento de Parasitologia Animal, Universidade Federal Rural do Rio de Janeiro (UFRRJ), Caixa postal 74.508, CEP 23851-970, Seropédica, Rio de \\ Janeiro, Brazil
}

Received 3 November 2016; accepted 5 June 2017

Available online 29 November 2017

\begin{abstract}
This study aimed to report the occurrence of species of nematodes in wild carnivore mammals from a locality of Atlantic forest in Brazil. Specimens of wild carnivore mammals of 3 species were necropsied: Chrysocyon brachyurus (Illiger, 1815), Cerdocyon thous (Linnaeus, 1766), and Puma (Herpailurus) yagouaroundi (É. Geoffroy, 1803). Seven species of nematodes were recorded: 5 in C. brachyurus [Uncinaria stenocephala (Railliet, 1884), Dioctophyma renale (Goeze, 1782), Strongyloides sp., Trichuris vulpis (Froelich, 1789), and Oslerus (Oslerus) sp.]; 2 in C. thous [Angiostrongylus raillieti (Travassos, 1927), and Strongyloides sp.], and only 1 species [Cylicospirura subaequalis (Molin, 1860)] in P. (H.) yagouaroundi. Strongyloides sp., T. vulpis and Oslerus (Oslerus) sp. were recorded for the first time in C. brachyurus from Brazil, and the first one of $C$. subaequalis in a host from Brazil in their type host since the original description date from 1860.

(C) 2017 Universidad Nacional Autónoma de México, Instituto de Biología. This is an open access article under the CC BY-NC-ND license (http://creativecommons.org/licenses/by-nc-nd/4.0/).
\end{abstract}

Keywords: Parasitic nematodes; Brazil; Wild mammals

\section{Resumen}

El objetivo de este estudio fue registrar la presencia de especies de nemátodos en mamíferos carnívoros salvajes de una localidad del bosque atlántico en Brasil. Ejemplares de 3 especies de mamíferos carnívoros silvestres fueron necropsiados: Chrysocyon brachyurus (Illiger, 1815), Cerdocyon thous (Linnaeus, 1766) y Puma (Herpailurus) yagouaroundi (É. Geoffroy, 1803). Se registraron 7 especies de nemátodos: 5 en C. brachyurus uncinaria stenocephala (Railliet, 1884), Dioctophyma renale (Goeze, 1782), Strongyloides sp., Trichuris vulpis (Froelich, 1789) y Oslerus (Oslerus) sp.; 2 en C. thous (Angiostrongylus raillieti [Travassos, 1927] y Strongyloides sp.) y solo una especie (Cylicospirura subaequalis [Molin, 1860]) en $P$. (H.) yagouaroundi. Strongyloides sp., T. vulpis y Oslerus (Oslerus) sp. fueron colectados por primera vez en C. brachyurus de Brasil, mientras que $C$. subaequalis se registra en su hospedador tipo en Brasil desde la descripción original hecha en 1860.

(C) 2017 Universidad Nacional Autónoma de México, Instituto de Biología. Este es un artículo Open Access bajo la licencia CC BY-NC-ND

(http://creativecommons.org/licenses/by-nc-nd/4.0/).

Palabras clave: Nemátodos parásitos; Brasil; Mamíferos silvestres

\footnotetext{
* Corresponding author.

E-mail address: barbaramarun@gmail.com (B.M. Rocha).
}

Peer Review under the responsibility of Universidad Nacional Autónoma de México. 


\section{Introduction}

The first reports of helminths in wild carnivore mammals from Brazil were made by Rudolphi (1819), who described the cestode Taenia crassipora Rudolphi, 1819 and the nematode Toxocara alienata (Rudolphi, 1819), both collected in the intestine of Nasua nasua (Linnaeus, 1766). Until the early 20th Century, one of the most significant contributions to the study of helminths of wild carnivores from Brazil was that of Diesing $(1850,1851)$, in which a total of 18 species of nematodes, cestodes, acanthocephalans, and trematodes, were described and reported.

The first helminth species described in wild carnivore mammals by Brazilian researchers was the nematode Uncinaria carinii Travassos, 1915, collected in the intestine of Cerdocyon thous (Linnaeus, 1766) in the municipality of São Paulo, State of São Paulo (Travassos, 1915). Since then, according to the checklist of helminth parasites in wild carnivore mammals from Brazil (Vieira, Luque, \& Muniz-Pereira, 2008), 21 species of hosts are reported for a total of 95 helminth species. After the study of Vieira et al. (2008) some new records of helminths in this group of hosts were reported (see Filoni et al., 2009; Gallas \& Silveira, 2011; Gallas, Silveira, \& Périco, 2014; Gomes, Olifiers, Santos, Simões, \& Maldonado, 2015; Gomes, Olifiers, Souza, et al., 2015; Lux-Hoppe, Araújo-de Lima, Tebaldi, \& Nascimento, 2010; Pinto, Knoff, Gonçalves, Sanches, \& Noronha, 2009; Ribeiro, Verocai, \& Tavares, 2009; Suárez, Pesenti, Macedo, Mascarenhas, \& Müller, 2015; Vieira, Luque, Souza-Lima, Moraes-Neto, \& Muniz-Pereira, 2012; Vieira, Muniz-Pereira, et al., 2012; Vieira et al., 2013). This demonstrates the potential for discovery of new data on the helminth parasites in wild carnivore mammals in Brazil.
The current study aimed to report the species of nematodes found in wild carnivore mammals from the municipality of Juiz de Fora, Minas Gerais state, Brazil.

\section{Materials and methods}

Twelve specimens of 3 species of wild carnivore mammals (Table 1) were necropsied, between June 2002 and January 2010: Chrysocyon brachyurus (Illiger, 1815) (Carnivora, Canidae) (Maned Wolf) (5 specimens), Cerdocyon thous (Linnaeus, 1766) (Carnivora, Canidae) (Crab-eating Fox) (6 specimens), and Puma (Herpailurus) yagouaroundi (É. Geoffroy, 1803) (Carnivora, Felidae) (Jaguarundi) (1 specimen). The hosts examined were accidentally 'road killed' and were donated by the Regional Office of the Instituto Brasileiro do Meio Ambiente e dos Recursos Naturais Renováveis (IBAMA), in the municipality of Juiz de Fora, in the state of Minas Gerais $\left(21^{\circ} 41^{\prime} 20^{\prime \prime} \mathrm{S}, 43^{\circ} 20^{\prime} 40^{\prime \prime}\right.$ W). The hosts were identified according to Berta (1982), Dietz (1985), and Oliveira (1998).

The nematodes collected were fixed in AFA for $48 \mathrm{~h}$, and preserved in $70 \%$ ethanol with $5 \%$ glycerin. For light microscopy studies, the nematodes were cleared in Amann's lactophenol, and mounted on temporary slides.

Identification and classification of nematodes to the generic level follow Anderson, Chabaud, and Willmott (2009) and Gibbons (2010). The specific identification follows Grisi (1971), Junker et al. (2013), Travassos (1927), Vicente, Rodrigues, Gomes, and Pinto (1997), and Waid and Pence (1988).

Voucher specimens are deposited in the Instituto Oswaldo Cruz Helminthological Collection (CHIOC), Rio de Janeiro, Brazil (Table 1).

Table 1

Quantitative data of nematode species reported in 3 species of wild carnivore mammals in the state of Minas Gerais, Brazil $(\%=$ prevalence, $\mathrm{M}=$ mean intensity, $\mathrm{SD}=$ standard deviation).

\begin{tabular}{|c|c|c|c|c|c|c|}
\hline & \multicolumn{2}{|c|}{$\begin{array}{l}\text { Chrysocyon brachyurus } \\
(n=5)\end{array}$} & \multicolumn{2}{|c|}{$\begin{array}{l}\text { Cerdocyon thous } \\
\quad(n=6)\end{array}$} & \multicolumn{2}{|c|}{$\begin{array}{c}\text { Puma }(H .) \text { yagouaroundi } \\
(n=1)\end{array}$} \\
\hline & $\%$ & $\mathrm{M} \pm \mathrm{SD}$ & $\%$ & $\mathrm{M} \pm \mathrm{SD}$ & $\%$ & $\mathrm{M} \pm \mathrm{SD}$ \\
\hline \multicolumn{7}{|l|}{ Ancylostomatoidea } \\
\hline $\begin{array}{l}\text { Uncinaria stenocephala } \\
\text { (CHIOC 35935) }\end{array}$ & 60 & $33 \pm 16$ & - & - & - & - \\
\hline \multicolumn{7}{|l|}{ Dioctophymatoidea } \\
\hline $\begin{array}{l}\text { Dioctophyma renale } \\
\text { (CHIOC 35932) }\end{array}$ & 60 & $1.66 \pm 1.15$ & - & - & - & - \\
\hline \multicolumn{7}{|l|}{ Metastrongyloidea } \\
\hline $\begin{array}{l}\text { Angiostrongylus raillieti }{ }^{\mathrm{a}} \\
\text { (CHIOC } 35930)\end{array}$ & - & - & 20 & 19 & - & - \\
\hline $\begin{array}{l}\text { Oslerus (Oslerus) sp. } \\
\text { (CHIOC } 35929 \mathrm{c})\end{array}$ & 40 & $205.5 \pm 82.7$ & - & - & - & - \\
\hline Rhabditoidea & & & & & & \\
\hline $\begin{array}{l}\text { Strongyloides sp. } \\
\text { (CHIOC 35933) }\end{array}$ & 100 & $232.8 \pm 120.2$ & 100 & $227 \pm 131.2$ & - & - \\
\hline Spiruroidea & & & & & & \\
\hline $\begin{array}{l}\text { Cylicospirura subaequalis }{ }^{\mathrm{a}} \\
\text { (CHIOC 35931) }\end{array}$ & - & - & - & - & 100 & 27 \\
\hline Trichinelloidea & & & & & & \\
\hline $\begin{array}{l}\text { Trichuris vulpis }{ }^{\mathrm{a}} \\
\text { (CHIOC 35934) }\end{array}$ & 20 & 27 & - & - & - & - \\
\hline
\end{tabular}

\footnotetext{
${ }^{a}$ The nematodes were collected in only 1 host.
} 


\section{Results}

In the 3 wild carnivore mammal species studied herein, 7 nematodes species were recorded (Table 1). Oslerus (Oslerus) sp. (Filaroididae) was collected under the mucosa of the inner surface of the trachea and bronchii of $C$. brachyurus. Uncinaria stenocephala (Railliet, 1884) (Ancylostomatidae) was found in the small intestine of $C$. brachyurus. Specimens of Dioctophyma renale (Goeze, 1782) (Dioctophymatidae) were collected in the right kidney of $C$. brachyurus. Angiostrongylus raillieti (Travassos, 1927) (Angiostrongylidae) (=Angiostrongylus vasorum [Raillet, 1866] sensu Costa, Costa, \& Guimarães, 2003) were registered in the pulmonary artery of $C$. thous. Unidentified Strongyloides sp. (Strongyloididae) specimens were collected in the small intestine of $C$. brachyurus and in $C$. thous. Trichuris vulpis (Froelich, 1789) (Trichuridae) were found in the intestinal caecum of C. brachyurus. Specimens of Cylicospirura subaequalis (Molin, 1860) (Spirocercidae) were collected from the cysts in the inner wall of the stomach of $P$. $(H$.) yagouaroundi.

\section{Discussion}

The genus Oslerus was proposed to accommodate Filaria osler described by Cobbold (1879), in domestic dogs in Europe. Anderson (1978) divided the genus in 2 subgenera based on the presence [Oslerus (Anafilaroides) (Gerichter, 1949)] or absence [Oslerus (Oslerus) (Hall, 1921)] of vaginal sphincters. Our specimens lack vaginal sphincter, thus were included in the subgenus Oslerus (Oslerus). Olerus (Oslerus) osleri (Cobbold, 1879) is reported in wild and domestic canids in Europe, North America, Africa, Asia and Oceania (Dunsmore \& Spratt, 1979; Hare, 1930; Kotani et al., 1995; Ortlepp, 1945). However, reports of this nematode in South America are scarce, restricted to domestic dogs from Chile (Alcaíno \& Gorman, 1999; Muñoz, Fredes, Faúndes, Sanz, \& Gonzáles, 2007), and C. brachyurus from Brazil (Dias et al., 2012). However, this last report is doubtful because it was only based on clinical and coprological diagnosis of larval parasites. Due to significant morphological and morphometric differences between the males of the current study in comparison with previous morphological descriptions of Oslerus (Oslerus) osleri, we prefer to not identify them as O. (Oslerus) osleri. A more detailed study of the morphological features integrated with genetic studies of the specimens collected is necessary to verify that these specimens are a new species of Oslerus. Therefore, the current study is the first confirmed report Oslerus (Oslerus) parasitizing C. brachyurus from Brazil.

Reports of $D$. renale in wild hosts from Brazil document this nematode parasitizing, C. brachyurus and Lontra longicaudis (Olfers, 1818) (Carnivora, Mustelidae) (Diesing, 1851); $D$. renale has been widely reported in Brazil parasitizing domestic dogs and C. brachyurus (Vicente et al., 1997; Vieira et al., 2008); and less frequently in other carnivores as Galictis cuja (Molina, 1782), G. vittata (Schreber, 1776), N. nasua, Speothos venaticus (Lund, 1842), and Cerdocyon thous (Linnaeus, 1766) (Pesenti et al., 2012; Ribeiro et al., 2009; Vieira et al., 2008).
In Brazil, 12 species of the genus Trichuris Roederer \& Wagler, 1761 parasitizing several groups of mammals are reported (Vicente et al., 1997). However, only 2 species occur in carnivores: T. serratus (Linstow, 1879) in domestic canids and felids (Vicente et al., 1997), and T. vulpis in domestic dogs and cats, as well as in wild specimens of $C$. thous (Mundim, Oliveira-Júnior, Rodrigues, \& Cury, 2004; Vicente et al., 1997; Vieira et al., 2008). The current study reports for the first time the parasistim by T. vulpis in C. brachyurus in this country.

Four species of Uncinaria Froelich, 1789 parasitizing wild carnivores (Vieira et al., 2008) have been recorded in Brazil: Uncinaria bidens Lent \& Freitas, 1938 in N. nasua, and Procyon cancrivorus (Cuvier, 1798) (Vicente et al., 1997; Vieira et al., 2008); Uncinaria maxillaris (Molin, 1861) in Procyon cancrivorus (Vicente et al., 1997; Vieira et al., 2008); Uncinaria carinii Travassos, 1915 has been recorded only once in C. thous by Travassos (1915), and U. stenocephala, species was reported initially in Europe and USA as intestinal parasite of the canids of the genus Vulpes Frisch, 1775 (Erickson, 1944; Saeed, Maddox-Hyttel, Monrad, \& Kapel, 2006). In Brazil, this species was first recorded by Mundim et al. (1991) parasitizing C. brachyurus in the state of Minas Gerais, as in the present study.

Angiostrongylus raillieti was described by Travassos (1927) as Haemostrongylus railiieti, from $C$. thous in the municipality of São Paulo, in the state of São Paulo. According to Grisi (1971), A. raillieti should be considered a valid species and not a synonym of $A$. vasorum from Brazil. In the study by Costa et al. (2003), using specimens collected in domestic dogs from Brazil, the authors considered A. raillieti a synonym of A. vasorum. However, the molecular study conducted by Jefferies, Shaw, Viney, and Morgan (2009) supports the idea that A. vasorum does not occur in Brazil, based on the comparison of molecular characters of specimens of A. vasorum from Europe and South America, which corroborates with that affirmed by Grisi (1971).

Strongyloides Grassi, 1879 has a wide geographical distribution, mainly as parasite of mammals, but some species infect birds, reptiles and amphibians (Little, 1996a,b). Ten species of Strongyloides parasitizing several species of mammals in Brazil (Vicente et al., 1997). The only species of this genus recorded in Brazilian domestic dogs is S. stercoralis (Bavay, 1876) (Vicente et al., 1997), but so far it has not been recorded in wild carnivores of this country. Vieira et al. (2008) reported an undetermined species of Strongyloides parasitizing C. thous and G. cuja from Brazil. Therefore, the current study is the first report of Strongyloides sp. in C. brachyurus in Brazil.

Cylicospirura subaequalis was described by Molin (1860) as Spiroptera subaequalis Molin, 1860 in Puma concolor (Linnaeus, 1771) and $P$. $(H$.$) yaguaroundi from Brazil (Molin, 1860).$ This species is recorded in domestic and wild felids throughout the world (Bowman, Hendrix, Lindsay, \& Barr, 2002); however, after the description by Molin (1860) this species has never been registered again in Brazilian hosts until now, that we found this parasitizing $P$. $(H$.) yaguaroundi. These nematodes are inserted into cysts in the stomach wall of their hosts, which can cause severe pathologies (Bowman et al., 2002). 
Table 2

Updated list of helminth parasites of wild carnivore mammals from Brazil, after study of Vieira et al. (2008).

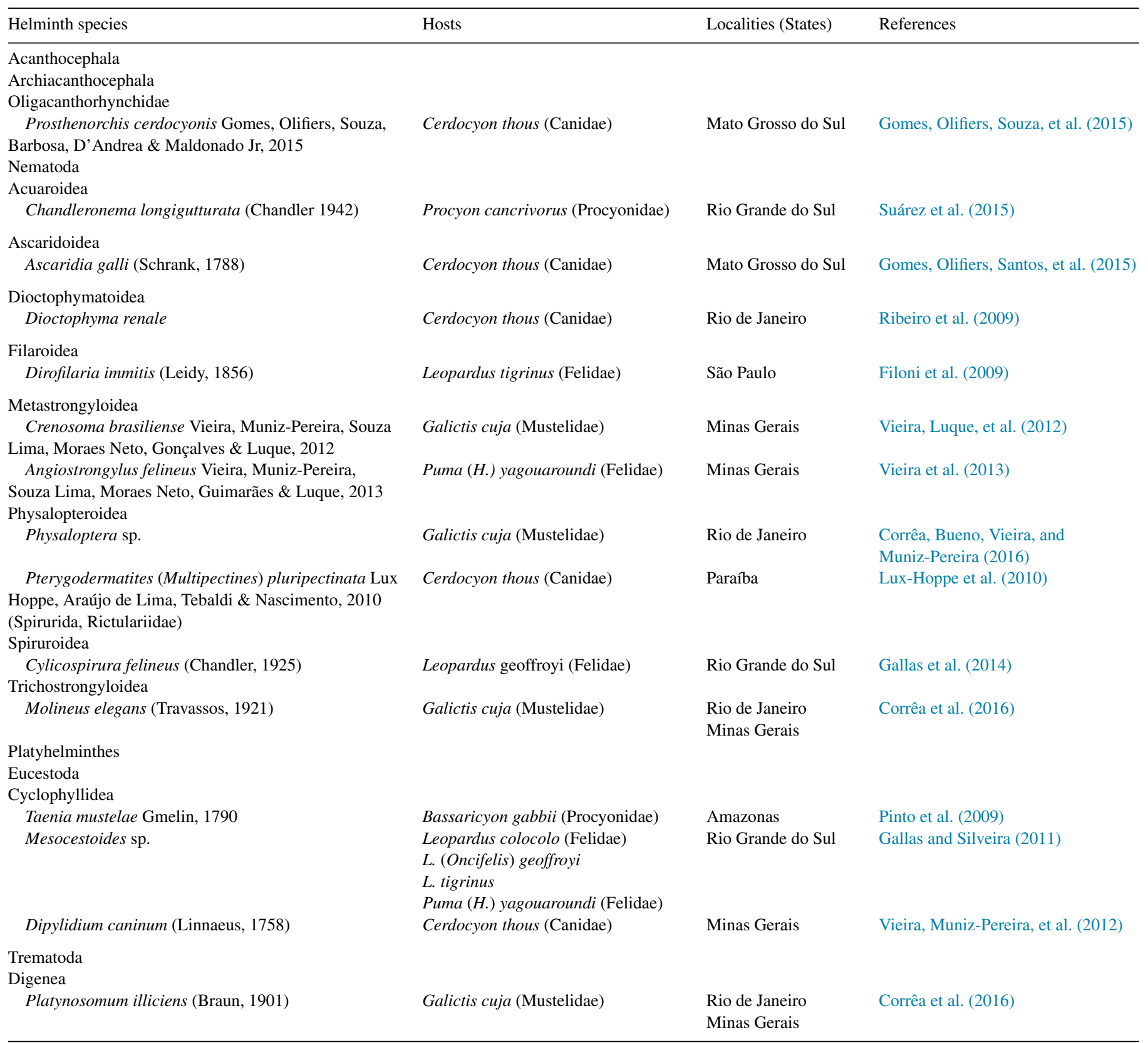

The most recent inventory of helminth parasites in wild carnivores in Brazil is the study of Vieira et al. (2008), which lists 95 helminth species in 21 species of this hosts group. After the publication of Vieira et al. (2008) and until the current study, no new information had been published about the helminth parasites of Brazilian wild carnivores (Table 2).

Data from the current study combined with data published after the study of Vieira et al. (2008) include 15 helminth species more not reported previously in these host species (Table 2), including 2 new hosts (B. gabbii, and L. colocolo) for helminth in the list of wild carnivore mammals from Brazil. Therefore, we can affirm that currently 109 helminth taxa in 23 species are reported for wild carnivores in Brazil.

\section{Acknowledgments}

Fabiano Matos Vieira was supported by a Postdoctoral fellowship from Programa Nacional de Pós-doutorado (PNPD) CAPES/FIOCRUZ (Fundação Instituto Oswaldo Cruz) at the Programa de Pós-graduação em Biodiversidade e Saúde (PPGBS) of the Instituto Oswaldo Cruz (IOC), Rio de Janeiro, RJ.

\section{References}

Alcaíno, H., \& Gorman, T. (1999). Parásitos de los animales domésticos en Chile. Parasitologia al Dia, 23, 33-41. 
Anderson, R. C. (1978). Keys to genera of the superfamily Metastrongyloidea. In R. C. Anderson, A. G. Chabaud, \& S. Willmott (Eds.), C.I.H. Keys to the nematode parasites of vertebrates (Vol. 5). Farnham Royal, Bucks, England: Commonwealth Agricultural Bureaux.

Anderson, R. C., Chabaud, A. G., \& Willmott, S. (2009). Keys to the nematode parasites of vertebrates. Wallingford, UK: CAB International.

Berta, A. (1982). Cerdocyon thous. Mammalian Species, 186, 1-4.

Bowman, D. D., Hendrix, C. M., Lindsay, D. S., \& Barr, S. C. (2002). Feline clinical parasitology. Iowa, USA: Iowa State University Press.

Cobbold, T. S. (1879). Parasites. A treatise on the Entozoa of man and animals including some account of the Ectozoa. London, UK: J.A. Churchill and Co.

Corrêa, P., Bueno, C., Vieira, F. M., \& Muniz-Pereira, L. C. (2016). Helminth parasites of Galictis cuja (Carnivora, Mustelidae), from localities in the Atlantic forest of Brazil. Brazilian Journal of Veterinary Parasitology, 25, $407-413$.

Costa, J. O., Costa, H. M. A., \& Guimarães, M. P. (2003). Redescription of Angiostrongylus vasorum (Baillet, 1866) and systematic revision of species assigned to the genera Angiostrongylus Kamensky, 1905 and Angiocaulus Schulz, 1951. Revue de Médecine Vétérinaire, 154, 9-16.

Dias, R. G., Legatti, E., Rahal, S. C., Teixeira, C. R., Ruiz-Júnior, R. L., Rocha, N. S., et al. (2012). Oslerus osleri (Cobbold, 1876) infection in maned wolf (Chrysocyon brachyurus Illiger, 1815). Journal of Zoo and Wildlife Medicine, 43, 674-677.

Diesing, K. M. (1850). Systema Helminthum (Vol. I). Vindobonae: Wilhelmum Braumüller.

Diesing, K. M. (1851). Systema Helminthum (Vol. II). Vindobonae: Wilhelmum Braumuiller.

Dietz, J. M. (1985). Chrysocyon brachyurus. Mammalian Species, 234, 1-4.

Dunsmore, J. D., \& Spratt, D. M. (1979). The life history of Filaroides osleri in wild and domestic canids in Australia. Veterinary Parasitology, 5, 275-286.

Erickson, A. B. (1944). Helminths of Minnesota canidae in relation to food habits, and a host list and key to the species reported from North America. The American Midland Naturalist, 32, 358-372.

Filoni, C., Pena, H. F. J., Gennari, S. M., Cristo, D. S., Torres, L. N., \& Catão-Dias, J. L. (2009). Heartworm (Dirofilaria immitis) disease in a Brazilian oncilla (Leopardus tigrinus). Pesquisa Veterinária Brasileira, 29, 474-478.

Gallas, M., \& Silveira, E. F. (2011). Mesocestoides sp. (Eucestoda, Mesocestoididae) parasitizing 4 species of wild felines in Southern Brazil. Revista Brasileira de Parasitologia Veterinária, 20, 168-170.

Gallas, M., Silveira, E. F., \& Périco, E. (2014). First report from the State of Rio Grande do Sul, Brazil on Cylicospirura (Cylicospirura) felineus (Chandler, 1925) Sandground, 1932 (Nematoda, Spirocercidae) in Leopardus geoffroyi D’Orbigny \& Gervais, 1844 (Carnivora, Felidae). Neotropical Helminthology, 8, 349-355

Gibbons, L. M. (2010). Keys to the nematode parasites of vertebrates. Supplementary volume. Wallingford, UK: CAB International.

Gomes, A. P. N., Olifiers, N., Santos, M. M., Simões, R. O., \& Maldonado, A., Jr. (2015). New records of three species of nematodes in Cerdocyon thous from the Brazilian Pantanal wetlands. Brazilian Journal of Veterinary Parasitology, 24, 324-330.

Gomes, A. P. N., Olifiers, N., Souza, J. G. R., Barbosa, H. S., D’Andrea, P. S., \& Maldonado, A., Jr. (2015). New Acanthocephalan species (Archiacanthocephala: Oligacanthorhynchidae) from the Crab-eating Fox (Cerdocyon thous) in the Brazilian Pantanal Wetlands. Journal of Parasitology, 101, 74-79.

Grisi, L. (1971). Ocorrência de Angiocaulus raillieti (Travassos, 1927) comb n. em Canis familiaris L. (Nematoda, Protostrongylidae). Revista Brasileira de Biologia, 31, 27-32.

Hare, T. (1930). Chronic trachea-bronchitis of the dog due to Oslerus osleri (Cobbold, 1879). Proceedings of the Royal Society of Medicine, 23, 1715-1718.

Jefferies, R., Shaw, S. E., Viney, M. E., \& Morgan, E. R. (2009). Angiostrongylus vasorum from South America and Europe represent distinct lineages. Parasitology, 136, 107-115

Junker, K., Lane, E. P., McRee, A. E., Foggin, C., van Dyk, D. S., \& Mutafchiev, Y. (2013). Two new species of Cylicospirura Vevers, 1922 (Nematoda: Spirocercidae) from carnivores in southern Africa, with validation of the related genera Gastronodus Singh, 1934 and Skrjabinocercina Matschulsky, 1952. Folia Parasitologica, 60, 339-352.

Kotani, T., Horie, M., Yamaguchi, S., Tsukamoto, Y., Onishi, T., Ohashi, F., et al. (1995). Lungworm, Filaroides osleri, infection in a dog in Japan. Journal of Veterinary Medical Science, 57, 573-576.

Little, M. D. (1996a). Comparative morphology of 6 species of Strongyloides (Nematoda) and redefinition of the genus. Journal of Parasitology, 52, 69-84.

Little, M. D. (1996b). Seven new species of Strongyloides (Nematoda) from Lousiana. Journal of Parasitology, 52, 85-97.

Lux-Hoppe, E. G., Araújo-de Lima, R. C., Tebaldi, J. H., \& Nascimento, A. A. (2010). Pterygodermatites (Multipectines) pluripectinata n. sp. (Spirurida: Rictulariidae), a nematode parasite of the crab-eating fox Cerdocyon thous (Linnaeus, 1766) from Caatinga shrubland, Brazil. Journal of Helminthology, 84, 312-316

Molin, R. (1860). Una monografia del genere Spiroptera. Sitzungsberichte der Akademie der Wissenschaften in Wien, 38, 911-1005.

Mundim, M. J. S., Machado, M. I., Bevilaqua, E., Mundim, A. V., Maywald, P. G., \& Oliveira, M. G. (1991). Ocorrência e identificação de Ancilostomatídeos em lobo-guará (Chrysocyon brachyurus, Illiger, 1811) da região do Triangulo Mineiro, Minas Gerais, Brazil. Brazilian Journal of Veterinary Research and Animal Science, 28, 39-43.

Mundim, T. C. D., Oliveira-Júnior, S. D., Rodrigues, D. C., \& Cury, M. C. (2004). Frequiência de helmintos em gatos de Uberlândia, Minas Gerais. Arquivo Brasileiro de Medicina Veterinaria e Zootecnia, 56, 562-563.

Muñoz, L., Fredes, F., Faúndes, P., Sanz, L., \& Gonzáles, C. (2007). Tos crônica en un perro asociada a Filaroides osleri. Parasitologia Latinoamericana, 62, $72-75$.

Oliveira, T. G. (1998). Herpailurus yagouaroundi. Mammalian Species, 578, $1-6$

Ortlepp, R. J. (1945). The lung worm, Filaroides osleri (Cobbold) in South African bred dogs; preliminary note. Journal of the South African Veterinary Medical Association, 16, 86-88.

Pesenti, T. C., Mascarenhas, C. S., Krüger, C., Sinkoc, A. L., Albano, A. P. N., Coimbra, M. A. A., et al. (2012). Dioctophyma renale (Goeze, 1782) Collet-Meygret, 1802 (Dioctophymatidae) in Galictis cuja (Molina, 1782) (Mustelidae) in Rio Grande do Sul, Brazil. Neotropical Helminthology, 6, 301-305.

Pinto, R. M., Knoff, M., Gonçalves, A. Q., Sanches, M., \& Noronha, D. (2009). First report of Taenia mustelae (Eucestoda, Taeniidae) parasitizing the Bushy-tailed Olingo, Bassaricyon gabbii (Carnivora, Procyonidae) in South America with an updated checklist of cestodes from other American Procyonid hosts. Neotropical Helminthology, 3, 7-14.

Ribeiro, C. T., Verocai, G. G., \& Tavares, L. E. R. (2009). Dioctophyme renale (Nematoda, Dioctophymatidae) infection in the Crab-eating Fox (Cerdocyon thous) from Brazil. Journal of Wildlife Diseases, 45, 248-250.

Rudolphi, K. A. (1819). Entozoorum Synopsis cui Accedunt Mantissa Duplex et Indices Locupletissimi. Berlin: Sumptibus Augusti Rücker.

Saeed, I., Maddox-Hyttel, C., Monrad, J., \& Kapel, C. M. O. (2006). Helminths of red foxes (Vulpes vulpes) in Denmark. Veterinary Parasitology, 139, $168-179$.

Suárez, A. G. R., Pesenti, T. C., Macedo, M. R. P., Mascarenhas, C. S., \& Müller, G. (2015). Occurrence of Chandleronema longigutturata (Nematoda: Acuariidae) in Procyon cancrivorus in the Neotropical region. Revista Brasileira de Parasitologia Veterinária, 24, 105-107.

Travassos, L. (1915). Uncinaria carinii n. sp. (nota prévia). Brazil Médico, 29, 79-80.

Travassos, L. (1927). Novos nematódeos. Boletim Biológico, 6, 52-61.

Vicente, J. J., Rodrigues, H. O., Gomes, D. C., \& Pinto, R. M. (1997). Nematóides do Brasil. Parte V: Nematóides de mamíferos. Revista Brasileira de Zoologia, 14, 1-452.

Vieira, F. M., Luque, J. L., \& Muniz-Pereira, L. C. (2008). Checklist of helminth parasites in wild carnivore mammals from Brazil. Zootaxa, 1721, 1-23.

Vieira, F. M., Luque, J. L., Souza-Lima, S., Moraes-Neto, A. H. A., \& MunizPereira, L. C. (2012). Dipylidium caninum (Cyclophyllidea, Dipylidiidae) in a wild carnivore from Brazil. Journal of Wildlife Diseases, 48, 233-234.

Vieira, F. M., Muniz-Pereira, L. C., Souza-Lima, S., Moraes-Neto, A. H. A., Gonçalves, P. R., \& Luque, J. L. (2012). Crenosoma brasiliense sp. n. 
(Nematoda: Metastrongyloidea) parasitic in lesser grison, Galictis cuja (Molina, 1782) (Carnivora, Mustelidae) from Brazil, with a key to species of Crenosoma Molin, 1861. Folia Parasitologica, 59, 187-194.

Vieira, F. M., Muniz-Pereira, L. C., Souza-Lim, S., Moraes-Neto, A. H. A., Guimarães, E. V., \& Luque, J. L. (2013). A new Metastrongyloidean species (Nematoda) parasitizing pulmonary arteries of Puma (Herpailurus) yagouaroundi (É. Geoffroy, 1803) (Carnivora, Felidae) from Brazil. Journal of Parasitology, 99, 327-331.

Waid, D. D., \& Pence, D. B. (1988). Helminths of mountain lions (Felis concolor) from southwestern Texas with a redescription of Cylicospirura subaequalis (Molin, 1860) Vevers, 1922. Canadian Journal of Zoology, 66 , 2110-2117. 